śląsko-słowacko-węgierskiego (Mieczysława Adamczyka), gimnazjum chyrowskiemu i jego wychowankom (Ewy Kuli i Marzeny Pękowskiej), sprawozdaniom szkolnym gimnazjów galicyjskich (Adama Horbowskiego), szkolnictwu zawodowemu Galicji Wschodniej (Bohdana Dobrianskiego), rozwojowi polskiej oświaty w Księstwie Cieszyńskim w drugiej połowie XIX wieku (Grażyny Kempy), kierunkom i formom polskiej oświaty dorosłych w Galicji przełomu XIX i XX wieku - rozwijanej przede wszystkim w ramach Towarzystwa Szkoły Ludowej i Towarzystwa Uniwersytetu Ludowego im. A. Mickiewicza (Agnieszki Stopińskiej-Pająk), udziałowi Towarzystwa Nauczycieli Szkół Wyższych w integrowaniu nauczycieli szkół średnich Galicji w latach 1884-1909 (Barbary Luczyńskiej), działalności Towarzystwa Gimnastycznego „SokóY” (Marka Mirkiewicza).

Teksty zamieszczone o omawianym tomie charakteryzuje w sumie dość zróżnicowany poziom merytoryczny a zarazem duża różnorodność tematyczna. Tę ostatnią cechę traktować jednak można jako jego zaletę, podnosząca zdecydowanie walory ksiażiki.

Weslaw Jamrożek

\title{
Edward Kołowski, Eugenia Malewska, Wychowanie do pracy na roli w rozwoju dziejowym, Olsztyn 1993, Wydawnictwo Akademii Rolniczo-Technicznej, ss. 138
}

Ksiażka E. Kołowskiego i E. Malewskiej pt: „Wychowanie do pracy na roli w rozwoju dziejowym" adresowana jest glównie do studentów akademii rolniczych, przygotowujących się do pracy w szkołach rolniczych. Ma charakter podręcznika niezbędnego i przydatnego w studiach nad dziejami wychowania do pracy na roli. Poszerza też znacząco nader jeszcze skromna historiografię tej problematyki.

Praca E. Kolowskiego i E. Malewskiej jest historycznym spojrzeniem na problematyke edukacji rolniczej $w$ powiązaniu $\mathrm{z}$ takimi istotnymi uwarunkowaniami, jak: przemiany polityczne i spoìeczno-ekonomiczne, myśl pedagogiczna i praktyka wychowawcza, rozwój nauk przyrodniczych, ekonomicznych i kultury wsi, zmiany świadomości chłopskiej itp. Analizowaną problematykę ujęto $w$ trzech obszernych rozdziałach.

Rozdział I zatytułowany „Wychowanie do pracy na roli w starożytności” traktuje o tej dziedzinie wychowania na Dalekim i Bliskim Wschodzie, Grecji i Rzymie. Na tle ogólnych koncepcji wychowania, kultury, rolnictwa Autorzy prezentują tu pierwsze $w$ historii próby wychowania rolniczego.

W rozdziale II pt. „Średniowieczne rolnictwo i wychowanie ludności rolniczej" przedstawione zostały zagadnienia dotyczace ustroju rolnego, stosunków gospodarczo-społecznych, ideałów wychowawczych $w$ Europie oraz w Polsce, które stanowią kontekst rozważań nad poczatkami oświaty $i$ wychowania rolniczego, geneza form przekazywania wiedzy zawodowej, wychowaniem ludności wiejskiej i sposobami upowszechniania wiedzy rolniczej.

W ostatnim i najobszerniejszym III rozdziale pt. „Podłoże społeczno-ekonomiczne i kulturowe edukacji rolniczej do końca XVIII w." Autorzy omawiają przemiany społecznogospodarcze wsi europejskiej oraz przełomy intelektualno-cywilizacyjne i konsekwencje oświatowe w Europie, ukazując ich wpływ na rozwój edukacji rolniczej. Omówione tu zostały początki szkolnictwa rolniczego w Europie i w Polsce, zwlaszcza wnikliwie w dobie Komisji Edukacji Narodowej. Rozdział kończą rozważania na temat wychowania folwarcznego, z uwypukleniem wpływu religii i dworu.

Książka E. Kołowskiego i E. Malewskiej oparta jest na głębokiej znajomości przedmiotu i rzetelnie przedstawia opisywane fakty. $Z$ racji jednak na zaznaczony przez Autorów w Przedmowie podrecznikowy charakter omawianego opracowania należy się tu także ustosunkować do jego funkcji dydaktycznych.

Podręcznik ten posiada $\mathrm{z}$ pewnością duże walory informacyjne. Podstawowym źródłem 
informacji jest tu opis faktów i ich wyjaśnianie, z dominacją jednakże zdań opisowych nad wyjaśniającymi. Może to rodzić zagrożenie, iż student postrzegać będzie proces historyczny jako potok faktów, bez dostrzegania zachodzących między nimi związków czasowo-przestrzennych i przyczynowo-skutkowych. Niedosyt budzi też brak - w odniesieniu do omawianych problemów - pytań, zadań i dyrektyw badawczych, które ukierunkowałyby prace odkrywczq studentów, samodzielne dochodzenie do wyjaśnień $\mathrm{i}$ ocen ewolucji edukacji rolniczej na przestrzeni dziejów. Lukę te kompensuje w części zamieszczony po każdym rozdziale wykaz literatury, która może stanowić źródło głębszego studiowania kwestii bedących przedmiotem szczególnego zainteresowania.

Dokonując oceny pracy E. Kolowskiego i E. Malewskiej w aspekcie dydaktycznym moż- na stwierdzić, iż jest to akademicki podręcznik systematyczny zawierający kompendium wiedzy z zakresu wychowania do pracy na roli, spełniający głównie funkcję informacyjno-poznawczą. Opracowanie podręcznika w takiej formie i treści ma swoje dydaktyczne uzasadnienie w realizowanych w uczelniach rolniczych zajęciach dydaktycznych i programach studiów z zakresu historii wychowania i oświaty rolniczej, które charakteryzują się szczupłością godzin dydaktycznych, niewspólmierną do zakresu treści kształcenia.

Stąd też poczynione tu uwagi krytyczne nie moga przesłonić walorów omawianej pracy. Jest ona $\mathrm{z}$ pewnością wartościową pozycją naukowa i dydaktyczną w polskiej literaturze dotyczącej historii edukacji rolniczej, jak i historii wychowania.

Alicja Kicowska

\section{Nauki pedagogiczne w Polsce. Tradycje - wspótczesność - przyszlośćc Materialy z konferencji, red. S. Michalski, R. Ossowski, Bydgoszcz 1994, Wydawnictwo WSP, ss. 561}

We wrześniu 1989 roku odbyła się zorganizowana przez Wyższą Szkołę Pedagogiczną w Bydgoszczy i Bydgoskie Towarzystwo Naukowe sesja $\mathrm{z}$ okazji 20-lecia WSP i 30-lecia PBTN-u. Jednym z organizatorów sesji i redaktorem niniejszego tomu byl Profesor Stanisła'w Michalski, który nie doczekał zlinalizowania prac. Zmarł w grudniu 1990 roku.

Tom otwierają wystąpienia R. Ossowskiego i J. Hellwiga poświęcone Profesorowi S. Michalskiemu. Pierwszą zasadniczą część pracy stanowia natomiast teksty omawiajace dzieje polskiej myśli pedagogicznej od czasów Odrodzenia (D. Żołądż), przez Oświecenie (K. Mrozowska), czasy rozbiorów (S. Gawlik, $\mathrm{Cz}$. Majorek, K. Poznański), aż do czasów współczesnych (S. Palka).

Następny blok poświęcony jest zagadnieniom poszczególnych dziedzin pedagogiki. I tak pedagogikę ogólną, jej stan i kierunki rozwoju omawia J. Gnitecki, dydaktykę - B. Niemierko, pedagogikę społeczną - E. Trempała, E. Stucki - stan i tendencje rozwoju pedagogiki wczesnoszkolnej, a K. Błoch-Žuchelkowska - geneze i rozwój pedagogiki przedszkolnej. Następnie I. Jundzilł zajmuje się problematyka pedagogiki opiekuńczej, R. Ossowski - pedagogika specjalną, A. Mońka-Stanikowa - pedagogika porównawcza. Artykuł A. Tchorzewskiego omawia genezę i rozwój teorii wychowania w Polsce, a T. Jałmużny rozwój pedeutologii. Pedagogika pracy zajął się Z. Wiatrowski, a E. Rogalski rozwojem powszechnej edukacji muzycznej. Tom zamykaja dwie rozprawy autorów niemieckich. Pierwsza J. Kuhnena poświęcona jest zagadnieniom wychowania dla przyszłości i $\mathrm{K}$. D. Mendego dotyczy stanu nauk pedagogicznych w Republice Federalnej Niemiec.

Poszczególne rozprawy uzupelniaja obcojęzyczne streszczenia. 